\title{
DEMOGRAPHY OF THE BURROWING OWL IN BADlands NATIONAL PARK
}

\author{
MARK S. MARTELl $\bullet$ PATRICK T. REDIG $\downarrow$ JILL NIBE \\ THE RAPTOR CENTER $\downarrow$ THE UNIVERSITY OF MINNESOTA \\ ST. PAUL
}

\section{$\checkmark$ EXECUTIVE SUMMARY}

The burrowing owl (Athene cunicularia), was once widely distributed throughout the western United States and Canada (Bent 1938), and was considered common on the prairie dog towns of South Dakota and Nebraska (Cooke 1888, Over and Thomas 1920). Recently however, concern over the birds status has resulted in its being listed as; "endangered" in two states (MN and IA), "threatened" across its range in Canada, and of "special concern" in seven states (WA, OR, CA, MT, WY, ND, FL) (Martell 1990). Land management practices including grazing, shooting, and poisoning on prairie dog colonies, the primary nesting habitat of burrowing owls in the Great Plains, has the potential to greatly affect owl populations. Information on population sizes and trends, the location of wintering areas, and the degree of nest site fidelity is needed to monitor and manage this species on public lands.

The objectives of this project are to:

1. determine the number and distribution of burrowing owls in Badlands National Park (BNP) and adjacent areas;

2. develop a census technique which will allow for continued monitoring of the Park's population, and;

3. document the degree of natal and nest-site fidelity of burrowing owls in southwestern South Dakota.

\section{$\checkmark \quad$ METHODS}

In consultation with BNP biologists, five prairie dog towns were chosen for repeated surveys in Badlands National Park; Burns Basin, Kocher Flats, Sage Creek, Tyree Basin, and Roberts (Table 1). Fifteen additional survey sites were selected in the Conata Basin (CNB) for surveys (Table 1).

Surveys to locate owls were conducted in spring, between 1 May and $8 \mathrm{May}$, and during the summer, between 19 June and 24 July. Trapping and banding of owls was done between 29 June and 25 July.

Owls were located by visually searching active and abandoned prairie dog towns, using binoculars and $20-60 \mathrm{X}$ spotting scopes. Site visits when owls were counted were of two types; 1 ) visits for banding owls, checking burrows, or conducting short nonsystematic searches of a town; or, 2) systematic searches of towns to collect data for developing a repeatable survey technique. This second type involved walking along a transect line through the town and stopping for 10 minutes at points spaced $300 \mathrm{~m}$ apart.

The location of each bird seen was recorded on 1:24000 USGS topographic maps. The age and sex 
Table 1. Location, size, and number of visits to survey sites.

\begin{tabular}{lcll}
\hline Town & Hectares & \multicolumn{1}{c}{ Location } & \# of Visits \\
\hline Burns & 205 & TO3S R17E S17,19,20 & 7 \\
Kocher & 327 & TO3S R14E S1,2,11,12 & 4 \\
Sage & 190 & TO2S R14E S11,14,15,23 & 8 \\
Tyree & 119 & TO2S R15E S33,34 & 13 \\
Roberts & 130 & TO1S R15E S3 & 8 \\
BGG-03 & 12 & TO4S R17E S7 & 14 \\
BGG-04 & 65 & TO4S R16E S4,5 & 9 \\
BGG-05 & 50 & TO3S R16E S8 & 15 \\
BGG-11 & 166 & TO4S R15E S3 & 1 \\
BGG-12 & 51 & TO4S R15E S4 & 1 \\
BGG-18 & 176 & TO3S R16E S21,28,33 & 3 \\
BGG-19 & 8 & TO3S R16E S7 & 1 \\
BGG-31 & 72 & TO3S R15E S11 & 3 \\
BGG-33 & 229 & TO4S R16E S4,5 & 6 \\
BGG-34 & 56 & TO3S T16E S3,10 & 1 \\
BGG-35 & no data & TO3S R18E S5 & 1 \\
BGG-36 & 34 & TO3S R16E S11 & 1 \\
BGG-37 & 28 & TO3S R15E S12 & 2 \\
BGG-42 & 294 & TO3S R15E S24 & 1 \\
BGG-43 & 84 & TO4S R16E S2,3 & 1 \\
\hline & & & 1 \\
\hline
\end{tabular}

of the birds, which was determined by plumage patterns (Bent 1938, Grant 1965, Thomsen 1971) were also noted. Counts of juveniles were done after their emergence from the burrow. Active burrows, being those we found broods at, were marked with an orange wooden stake (placed $20 \mathrm{~m}$ north of the burrow). We also searched for owls which had been banded and color-marked in past years (Martell et al. 1990).

Haug-traps (Martell 1990) were used at burrows to catch juveniles and bal-chatri traps were used to catch adult birds. Trapped birds were banded with standard aluminum U. S. Fish and Wildlife Service bands (adults on the right leg, juveniles on the left leg) and yellow herculite bands (adults on the left leg, juveniles on the right leg). Morphometric measurements which included length of 7th primary, wing chord, foot pad length, mid-tarsal thickness, beak depth and length were taken at the time of banding (Baldwin et al. 1931). Requests for information on sightings of the color-marked birds were sent to American ornithological organizations and to biologists at universities and research organizations in Mexico.

\section{- RESUlTS AND DISCUSSION}

We surveyed 2297 ha of prairie dog town, 970 ha in BNP and 1327 ha in CNB. A total of 70 adult and 67 juvenile burrowing owls were seen during this 
survey. Twenty-seven adults making up 14 pairs were located in BNP, an average of 1 pair/60 ha. They were found on three towns; Burns, Tyree, and Kocher (Table 2). We saw no burrowing owls on either Roberts or Sage Creek. Twelve of these pairs successfully raised broods, and we counted a total of 29 juveniles (2.42 young/brood) (Table 2) in BNP.

Table 2. Numbers of burrowing owl seen on prairie dog towns in Badlands National Park.

\begin{tabular}{lcccc}
\hline \multicolumn{5}{c}{ Numbers of burrowing owls } \\
Town & \multicolumn{3}{c}{ Adults Pairs Juveniles } & Broods \\
& & & & \\
Burns Basin & 4 & 1 & 2 & 1 \\
Kocher Flats & 11 & 5 & 12 & 4 \\
Sage Creek & 0 & 0 & 0 & 0 \\
Tyree Basin & & & & \\
Town A & 9 & 6 & 9 & 5 \\
Town B & 3 & 2 & 6 & 2 \\
Roberts & 0 & 0 & 0 & 0 \\
\cline { 2 - 5 } & & & & \\
Totals & 27 & 14 & 29 & 12 \\
\hline
\end{tabular}

Nineteen pairs of owls were located on 10 of the 14 towns surveyed in the Conata Basin, and average of 1 pair/66 ha. Fourteen broods with a total of 33 juveniles were recorded (2.36 young/brood) (Table 3). One adult, and 31 juvenile owls were banded and color-marked during the course of this field season. The adult was captured using a balchatri on town 37 in the Conata Basin. All of the juveniles were captured using haug-traps. Seven juveniles were trapped in BNP, 19 were trapped on the Conata Basin, and 5 were trapped in Interior, SD. No owls were seen wearing color-bands from previous years.

Problems arose in two areas; trapping and analysis of transect line surveys. Our inability to successfully trap adult owls for banding will interfere with estimates of nest burrow fidelity in future years. However, our experiences this past year will hopefully lead to more successful trapping methods in the future.

Table 3. Number of burrowing owls seen on prairie dog towns in the Conata Basin, South Dakota.

Numbers of burrowing owls

Town Adults Pairs Juveniles Broods

\begin{tabular}{lllll} 
BGG & & & \\
03 & 1 & 2 & 4 & 2 \\
04 & 2 & 0 & 0 & 0 \\
05 & 11 & 6 & 9 & 3 \\
11 & 1 & 1 & 2 & 1 \\
12 & 0 & 0 & 0 & 0 \\
18 & 6 & 2 & 2 & 1 \\
19 & 1 & 1 & 3 & 1 \\
32 & 4 & 2 & 1 & 1 \\
33 & 4 & 2 & 5 & 2 \\
34 & 0 & 0 & 0 & 0 \\
36 & 0 & 0 & 0 & 0 \\
37 & 2 & 1 & 4 & 1 \\
42 & 1 & 1 & 1 & 1 \\
43 & 2 & 1 & 2 & 1 \\
\hline Total & 41 & 19 & 33 & 14
\end{tabular}

Burrow located outside of study area in Interior, SD

35

2

1

5

1 
Statistical analysis of transect surveys of wildlife require higher densities of target animals than were present in this study. This problem is not unique to this study, as most raptor populations have low densities. Recent work done by Paul Giessler and Mark Fuller at the U.S.F.W.S. Pautuxent Research Lab have led to statistical analysis techniques for woodland raptor populations. We are currently working with Dr. Fuller in analyzing our data using these techniques. Preliminary assessments suggest that our data will be ammenable to this technique. Analysis of data is expected to be completed for the final report.

\section{$\checkmark \quad$ LITERATURE CITED}

Baldwin, S. P., H. C. Oberholser, and L. G. Worley. 1931. Measurements of birds. Cleveland Mus. of Nat. Hist. 165 pp.

Bent, A. C. 1938. Life histories of North American birds of prey. Smithsonian Inst. U.S. Natl. Mus. Bull. 170. 482 pp.
Cooke, W. W. 1888. Report on bird migration in the Mississippi Valley 1884 and 1885. Bull. 2 U.S. Gov. Printing Office Wash., D.C.

Grant, R. A. 1965. The burrowing owl in Minnesota. Loon 37:2-17.

Martell, M. S. 1990. Reintroduction of burrowing owls into Minnesota: A feasibility study. M.S. Thesis, Univ. of Minn. 95 pp.

J. Schladweiler, and J. Nibe. 1990. Minnesota burrowing owl conservation report. Unpubl. The Raptor Center at Univ. of Minn., St. Paul, MN. 20 pp.

Over, W. H., and C. S. Thomas. 1920. Birds of South Dakota. So. Dak. Geol. and Nat. Hist. Surv. Bull. 9. Vermillion, S.D.

Thomsen, L. 1971. Behavior and ecology of burrowing owls on the Oakland Municipal Airport. Condor 73:177-192. 